\title{
A case of transverse vaginal septum causing obstructed labour
}

\author{
Saratu Bello*, Ukwu Eze, Adoke Umar
}

Department of Obstetrics and Gynecology, Usmanu Danfodiyo University Teaching Hospital Sokoto, Nigeria

Received: 29 October 2020

Accepted: 09 December 2020

\section{*Correspondence:}

Dr. Saratu Bello,

E-mail: drsbello2007@gmail.com

Copyright: (C) the author(s), publisher and licensee Medip Academy. This is an open-access article distributed under the terms of the Creative Commons Attribution Non-Commercial License, which permits unrestricted non-commercial use, distribution, and reproduction in any medium, provided the original work is properly cited.

\begin{abstract}
Transverse vaginal septum (TVS) is a congenital mullerian malformation resulting from failure of fusion or canalization of the urogenital sinus and the mullerian ducts. This results in amenorrhea, inability to consummate marriage and primary infertility if left untreated. It is a rare finding in pregnancy and labor. However, due to ignorance, poor health seeking behavior and poverty in our setting the diagnosis of transverse vaginal septum may only be encountered in labor. We describe an 18 year old primigravida at term presented with history and findings of obstructed labor due to transverse vaginal septum (low-type) with a small central aperture first diagnosed in labor. This report is aimed at alerting clinicians that all primigravidae should have a routine pelvic examination during their antenatal visit to ruleout lower genital abnormalities.
\end{abstract}

Keywords: Septum, Obstructed labor, Congenital mullerian malformation

\section{INTRODUCTION}

Transverse vaginal septum (TVS) results from faulty fusion or canalization of the urogenital sinus and mullerian ducts. Delaunay first described TVS in $1877 .{ }^{1}$ The cause is unknown, although some cases may be the result of a female sex linked autosomal recessive transmission. ${ }^{2}$ Various combinations may co-exist in a single subject. ${ }^{3}$ The incidence is approximately 1 in 30,000 to 1 in 80,000 women. ${ }^{4}$ Approximately, $45 \%$ occur in the upper vagina, $40 \%$ in the mid-portion and $15 \%$ in the lower vagina. ${ }^{5}$ When the septum is located in the upper vagina, it is likely to be patent, whereas those located in the lower part of the vagina are more often complete. Uterovaginal anomalies are classified into four groups. The first group is agenesis of uterus and vagina (Mayer Rokitansky-Kuster Hauser syndrome) due to dysplasia of mullerian ducts with absence of normal uterus and most or all of the vagina. The second group, disorders of vertical fusion result from faults in the junction between the downward growing mullerian ducts and upward growing derivatives of urogenital sinus and the vaginal bulbs. This group includes transverse vaginal septum and cervical agenesis. The third group consists of disorders of lateral fusion of the true mullerian ducts and failure of absorption of the uterine septum. The fourth group includes unusual configurations of vertical and lateral fusion defects. ${ }^{6}$

\section{CASE REPORT}

Mrs. J. S. was an 18 year old unbooked primigravida who was referred to the labor ward with two days history of labor pains. There was drainage of liquor, but no bleeding per vaginam. She perceived fetal movements. She had the urge to push but delivery was not imminent.

She was earlier managed at 15 years of age for primary amennorhoea and cyclical lower abdominal pain for 2 years on account of which she had a perineal surgery. The detail and the extent of surgery could not be ascertained. Thereafter she started menstruating.

On examination she was found to be a young lady in painful distress. She was not pale and afebrile. Abdominal examination revealed an enlarged uterus with palpable uterine contractions. The fetus was in a longitudinal lie, presenting cephalic with descent of $2 / 5$. The fetal heart rate was 165 beats per minute. A shallow vagina of about $3 \mathrm{~cm}$ 
in length was found with a blind end and a pinhole central opening. The vagina admitted two fingers. There was thickening of the vaginal walls due to fibrosis. The cervix was not felt. A diagnosis of obstructed labor due to a transverse vaginal septum was made. Results of investigations revealed packed cell volume of $32 \%$ and there was no protein, glucose or ketones in her urine. Blood was made available. She had an emergency lower segment caesarean section and was delivered of a severely asphyxiated female baby with Apgar scores of 2 and 3 minutes. ${ }^{1,5}$ The pinhole opening on the septum was dilated to aid the egress of lochia. The post-operative period was uneventful and she was discharged home to be seen at the post natal clinic after 6 weeks. She was further evaluated for other during the postnatal period for other suspected urogenital anomalies which was absent. She was seen as scheduled and was planned for excision of the septum.

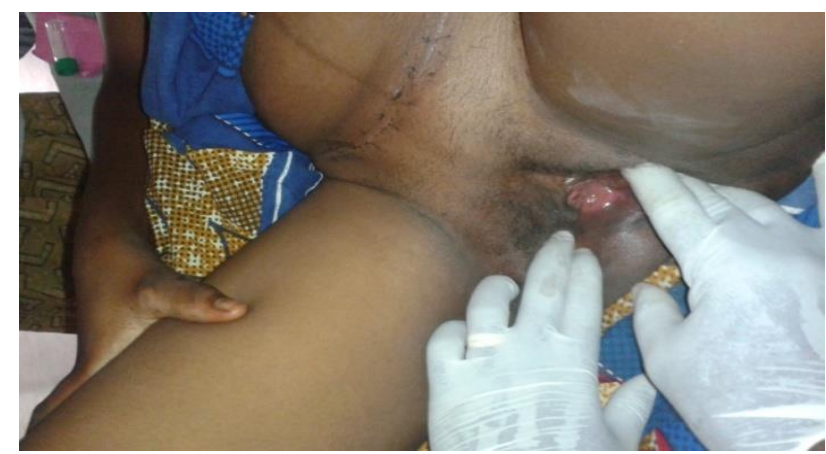

Figure 1: A transverse vaginal septum with a healed Pfernnesteil scar.

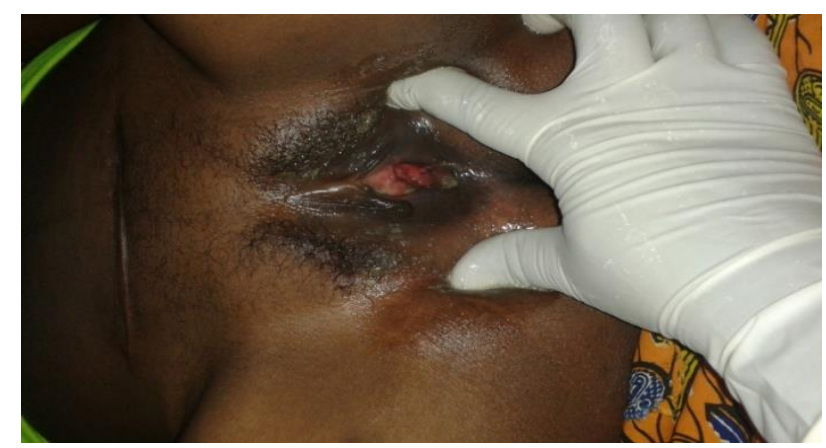

Figure 2: Transverse vaginal septum with a central aperture.

\section{DISCUSSION}

A wide variety of mullerian abnormalities have been described. A TVS can develop at any location in the vagina but is more common in the upper part of the vagina. ${ }^{2}$ The case presented was however found in the lower part of the vagina. Obstructed labor due to transverse vaginal septum have being described by various authors world over. Hugh et al, Ventolini et al and Malhotra et al among others have reported labor obstruction due to transverse vaginal septum..$^{7-9}$
Transverse vaginal septum causing obstruct labor is a rare finding. This presumably is because such patients would have presented earlier with complaint of cryptomenorrhoea, cyclical lower abdominal pain and among couples inability to consummate marriage and inadvertently infertility. The presence of a central opening on the septum is not a typical finding. It may have being created as a result of the previous surgery the patient has had. Hence with appropriate treatment, proper follow-up, and antenatal care this scenario could have being averted. However inappropriate treatment could result into the above case scenario. Also ignorance, poor health seeking behavior, poverty and lack of antenatal care in low resource setting like ours could also be a contributing factor.

A TVS can develop at any location in the vagina but is more common in the upper part of the vagina. ${ }^{2}$ The case presented was however found in the lower part of the vagina.

Most patients may present first menarche with cyclical lower abdominal pain, abdominal swelling and hematocolpos as it was reported in the index case. However, an incomplete septum is usually asymptomatic because the central aperture allows for vaginal secretions and menstrual flow from the vagina. TVS during pregnancy may lead to significant vaginal laceration, obstructed labour and caesarean section as was seen in this case. ${ }^{10}$ However, trail of labour may be successful as it was reported by Blanton. ${ }^{11}$ Surgical correction should follow an attempt to identify the extent of the lesion.

\section{CONCLUSION}

TVS in pregnancy resulting in obstructed labor is a rare finding. It is associated with attendant maternal and fetal morbidity and even mortality. Adequate management of patients with cryptomenorrhoea at menarche is paramount. Routine vaginal examination at antenatal care visits is beneficial especially in primigravida.

Funding: No funding sources Conflict of interest: None declared Ethical approval: Not required

\section{REFERENCES}

1. Delaunay. Etude Sue le Cloisonnement Transversal du vagin complete et imcomplet d'origine congenital. Thesis. Paris. 1877.

2. Reed MH, Griscom NT. Hydrometrocolpos in Infancy. Am J Roentgenol. 1973;118:1.

3. Ara S, Tahir S. Diagnosis and Management of Congenital anomalis of Vagina. Ann Punjab Med Coll. 2011;5:124.

4. Muram D. Pediatric and Adolescent Gynaecology. In: Decherney AH, Nathan L, Goodwin TM, Laufer N (eds). Current Diagnosis and Treatment in Obstetrics 
and Gynecology. 10th ed. MC Graw Hill Medical Publishing Division New York. 2007;540-69.

5. Dutta DC. Congenital Malformations of female genital organs. In Konar H (ed) DC Dutta Textbook of Gynecology. 5th ed. New Central Book Agency Kolkata. 2008;40-6.

6. Rock J, Breech L. Surgical Correction of Uterovaginal Anomalies. Glob Libr Women's Med. 2010;10:10048.

7. Arthur HR. Obstructed labor due to septate vagina. BJOG. 1948;55(6);766-9.

8. Ventolini G. Vaginal Septum in Adolescents: Clinical Implications. J Genit Syst Disor. 2013;e002.

9. Ustun Y, Zeteroglu S, Sahin G. A Case of transverse vaginal septum diagnosed during labour. Erciyes Med J. 2005;27(3):136-8.
10. Gary V, Sara J, Cory BJ, Ran N. Obstruction of Labor by a Vertical Lower Vaginal Septum: A Case Report and Review of the Literature. J Gynecol Surg. 2006;22(4):167.

11. Blanton EN, Rouse DJ. Trial of labor in women with Transverse Vaginal Septa. Obstet Gynecol. 2003;101:1110-2.

Cite this article as: Bello S, Eze U, Umar A. A case of transverse vaginal septum causing obstructed labour. Int J Reprod Contracept Obstet Gynecol 2021;10:350-2. 